\title{
Visions of Peace in the Middle East
}

\author{
For the Cousins' Club of Orange County, \\ October 31, 1992
}

Rabbi Beerman's speech, based on some fragmentary notes below, came at an eventful moment in the history of the Israeli-Arab conflict. Yitzhak Rabin had been elected prime minister four months earlier. He quickly signaled his willingness to reignite negotiations with the Arab states, especially after the Madrid peace conference of 1991, convened by Spain, the United States and the USSR, did not yield any breakthroughs. Unbeknownst to the world, the Rabin government also initiated secret back-channel discussions with Palestinians in Norway in the summer of 1992. It was on the basis of those conversations that Rabin, Israeli foreign minister Shimon Peres, and Palestinian leader Yasser Arafat signed the Oslo Accords on the South Lawn of the White House on September 13, 1993.

Beerman did not know of the secret Norwegian negotiations in 1992. But he had a good sense of the key issues. He recalls in this speech the origins of his own deep connection to the land, when on his first visit in 1947 he was struck by the beauty of the land, the dynamism of the Zionist settlers, and the dangers of chauvinism. He then moved on in his remarks to a clear-headed analysis of some of the key problems at the center of the conflict. The Israeli settlement project in the West Bank, he noted, would be a serious obstacle. At the time of the speech, there were 100,0oo Israeli settlers; today, there are nearly a half million, whose presence renders difficult the idea of a territorially viable Palestinian state.

Mindful of the decades of enmity between Jews and Arabs, Beerman was sensitive to the fact that the Palestinians had not yet received much tangible benefit from peace negotiations. The Camp David Accords promised them a limited form of local autonomy that was never realized. And despite his support for the Oslo peace process, Prime Minister Rabin never affirmed publicly the right of the Palestinians to a state 
of their own. Beerman understood that concrete and meaningful gestures had to be made by the Israelis in order to make the Palestinians recognize the value of peace. This was not only a matter of strategic wisdom, but-in typical Beerman form-of moral necessity. As a whole, the speech below contains an interesting mix of autobiographical insight, prophetic remonstration, and prescient realism.

The Negotiations-historic is an overused word, yet for the first time in the history of the conflict, we have negotiations between Palestinians, the Arab States, and the Israelis, with all sides agreeing on the principle of exchanging land for peace (i.e., they agree that Resolution 242 applies to the West Bank and the Golan Heights).

There is reason for some optimism. While Yitzhak Shamir intended, by his own admission, to stall the autonomy negotiations and thought it possible to drag them out for ten years, Rabin has stated his desire to conclude them in nine months. With the new Israeli government it is possible to believe that someday this conflict will end; someday there will be real peace.

Still there are reasons to be cautious. The issues that separate the Israeli government from the Palestinian negotiators are fundamental. (E.g., 1. the Israeli government is opposed to the emergence of a Palestinian state, while for the Palestinians this is the basis on which they are prepared to make lasting peace with Israel. 2. Israeli and Palestinian politics are unstable. It will take many years to resolve the conflict; the Israeli right wing will have opportunities to return to power. On the Palestinian side, the centrists who are committed to negotiations will be under constant pressure from more radical nationalists who oppose these negotiations and from the fundamentalists who oppose any negotiations.)

There are many obstacles ahead. Each side views these negotiations as laying precedents that will bear powerfully on the final status that will only begin during the third year of the autonomy period. Thus even though these are negotiations over "interim" arrangements, they are vested with great importance-e.g., although Jerusalem is not a substantive topic now, any election plan will have to deal with [the] question of whether or not Palestinians living in East Jerusalem will be able to vote and run for office.

The U.S. will continue to be a major factor. Not just a question of U.S. policy, but also a question of the priority that the next President will give to the negotiations. The next Administration will be focusing on domestic issues, and its foreign policy concerns may give minimum attention to the Middle East.

SETTLEMENTS-Rabin announced that he will complete approximately 10,000 units of housing in the West Bank. These units [are] in various stages of construction. Some finished, others merely a hole in the ground. Will not go ahead with 7,00o planned by Shamir government. 10,000 units equals about 50,000 people over the 100,000 already there. 
Once upon a time, forty-five and a half years ago in the summer of 1947, bored by my studies at rabbinical school, and stimulated by a charismatic teacher, a world-renowned archaeologist with a passionate love for what was then called Palestine, I decided to spend a year of study at the Hebrew $U$ in Jerusalem. For \$250 I was able to make the fifteen-day voyage by ship from New York to Haifa, with a stop in Beirut, where the Jews onboard were forbidden to leave ship. It was a most glorious time to come, one that would profoundly shape my life and my thinking forever.

I was swept away by the beauty of the land and by the incredible dynamism of my Jewish brothers and sisters who had come there to build it and to be built by it. It was a most peaceful time and not a day was without its violence. British tanks patrolled the streets. Etzel and Lehi, Irgun and Stern Gang whose prominent leaders were Begin and Shamir, were at work, bombs; into cafes frequented by British soldiers, or at army installations. The walls everywhere marked with graffiti-al Habritim hakovshim, zohi artzenu-British invaders, out of our country-a rifle cut through a map of Palestine that included both sides of the Jordan, with the inscription rak kach-only in this way, with the rifle, with force.

My teacher had provided me with an introduction to Judah Magnes, President of the Hebrew University. He and Martin Buber had proposed the idea of a binational state of Jews and Arabs as the only reasonable and equitable solution to what was called "the problem of Palestine." I easily came under their influence. That year, 1947, the University opened on October 31. Magnes gave the address to the assembled faculty and student body on Mt. Scopus, passionately warning of the danger of the rising tide of Jewish nationalism. I sat there as the students roared their disapproval in a loud chorus of boos.

Meanwhile, at what was then called Lake Success in New York, the UN was debating the future of Palestine. On Nov. 29 the UN arrived at its historic decisionthat the land should be partitioned into two separate states, one Jewish, one Arab. There was great joy-for everyone, except for those rejectionists in the Irgun and the Stern Gang, and the Arabs, who the very next day erupted in acts of violence, and began their war against the decision, against us.

All the rest is familiar history: The creation of Israel in May of 1948, the departure of the British, the invasion of Arab armies, the flight of the Arabs, and for Jews the great victory, the great valor. The goal of the Zionist movement, it had always seemed to me, was the liberation of the Jewish people. Young and old died to create a Jewish society, just and equitable, at peace with its neighbors, secure in its own nation, on part of the historic Jewish homeland. Partition of the territory between Jordan and the Mediterranean into two states was accepted by the overwhelming majority of the Zionist movement as a necessary condition for maintaining Israel's particular Jewish vision. It was the principle of compromise through that partition that alone provided the basis for the broad international recognition of the 
legitimacy of Israel's $1948-1967$ borders despite the implacable opposition of the Arab nations and the Palestinians.

The hope of generations of Jews was repeatedly threatened by the relentlessness of Arab hostility. But following the Six-Day War in 1967 it would come to be threatened by something else: The hidden contradictions within Israel itselfthe desire to reach a settlement, certainly, but also territorial ambitions. The will to compromise, but also the belief in a particular and decisive right to the land of Israel.

In the years since 1967 , the moral credibility of the Jewish people would come to be tested in the occupied or administered territories, particularly in the last year (depending on which locution you prefer). "Was the wonder of our renewal as a people," Abba Eban would come to ask, "the ability to take a language, a land and a people separated for centuries, and to have brought them back together again in a new birth of independent life in the land of our ancestors, was that rebirth meant so that we might produce another nation state, like all of the others, living by the gun? Was it to create a homeland out of the energy of so much will and courage and sacrifice and imagination, so that Jews could have a land where children were beaten as a matter of routine? Where an enemy, however dangerous, could be buried alive? Where books were censored, dissidents imprisoned or sent into exile." Could a Jew, I wondered, a Jew, be at home in such a land?

The goal of the Zionist moment, which created Israel, was the normalization of the Jewish people. The bitter fruits of normalization in Israel made it possible for us to produce our farmers and scientists, our artists and writers, and always our courageous soldiers, and now our own share of sadists.

How could Jews permit their souls to be annexed by the territories they occupied?

When the Kahan Commission, which investigated the Sabra and Shatila massacres, charged General Arik Sharon with “indirect responsibility” for the murders, it quoted a passage from the Talmud, saying: "A basis for 'indirect responsibility' may be found in the outlook of our ancestors ... 'It is said in Deuteronomy (21:6f) that the elders of the city, who were near a slain victim who had been found (when it was not known who had struck him down), would wash their hands over the (victim) and state: 'Our hands did not shed this blood and our eyes did not see ...'”

Ours, as American Jews, we who loved Israel, we who fought for it, supported it, believed in it, ours, I believed, was surely the responsibility, at least the indirect responsibility - all of us, those who approved, those who were silent, those who joined the Israelis who criticized the policies of their government. The common wisdom had always declared that we who live outside of Israel owe deference to the Israelis because they and their children have fought the wars of Israel, and bear the risks of living in Israel, while we have merely provided money and political support. That it is our duty to accommodate to Israel's prevailing government and 
persuade our government to do the same. Those who are still charitably called American Jewish leaders have dutifully been willing to do that, regardless of their private feelings.

Now all of this is taking place against the backdrop of the opening of the peace talks. The prospects for peace are surely threatened by the settlements, since a peace inevitably will mean some sort of territorial compromise.

There is a real possibility to move forward toward peace, as never before in the past forty-four years. But whether the Israelis will turn the wish for peace into a decision to compromise on land is yet to be seen.

An October 1992 article in The Economist recounts that in 1937 Jabotinsky visited Britain's House of Lords to press the case for a Jewish state. He said he understood the desire of the Arabs to set up their state in Palestine, but that it had to be balanced against the disaster awaiting the Jews of Europe. The Arabs already had several states: When the Arab's claim for another one in Palestine was confronted with the Jewish claim to be saved, it was like "the claims of appetite vs. the claims of starvation."

Within a few years, Hitler had proved him tragically right. But that was onehalf century ago. Today we Jews have our sanctuary. The whole world is ready to accept Israel's permanence and legitimacy within legally defined borders. For Israel to demand the West Bank as well, on top of the territories gained in 1948, has become a claim of appetite. It is the claim of the Palestinians that is now the claim of starvation. Unless it is met, there will be no peace.

Over the past several months, there had been a marked decline in the incidence of popular violence, and there was a return to a more upbeat mood. Palestinians were holding large wedding celebrations, going out to rest. Israel had announced a cutback in the number of troops allotted to the territories, and as a gesture, had released some 800 prisoners, relatively low grade intifada offenders being held in detention camps.

Even today some 12,000 political prisoners are serving sentences-7,000 in IDF detention camps, 5,000 in security wings of [the] Israeli prison system. On September 27, these latter went on a hunger strike for better conditions.

Palestinians have little to show from the negotiating process. Their leaders have requested that Israel ease the tax burden, and travel restrictions, or release all prisoners-[the] Rabin government has not responded. Nor would Rabin agree that Israel reveal its plan for final settlement regarding the territories.

There are some positive signs. Latest Israeli proposal states that Administrative Council will be responsible to Palestinians. There is, for the first time, no reference to Judea and Samaria. Palestinians, of course, have asked that Israel state that 242 will apply to final settlement, that nothing will be done in the interim agreements to prejudice [an] ultimate solution.

Palestinians need to be promised something real after autonomy. U.S. is important! 


\section{COMMENTARY BY SALAM AL-MARAYATI}

In reading Leonard's analysis of the Palestinian-Israeli peace process, I saw one who was on a spiritual quest to transcend religious nationalism. He critiqued his own: "How could Jews permit their souls to be annexed by the territories they occupied?" He believed that religion has no value if it is imprisoned by power and is violating the rights of others. That's what I admired about Leonard the most-he was not a religious leader who clung to his own community at all costs (whether you are a rabbi or an imam or a priest); he added to the richness and to the complexity and to his sophistication, because he was both religious and spiritual-a rare combination in any individual. He moved beyond the dogma to uphold what is ethical. He exemplified what we find in our scripture: "O you who believe, stand up for equity and be witnesses to God even if you have to testify against yourself, your family, or your community ..." (Quran 4:135). It made him question himself, his congregation, and all of us on how to find truth and adhere to justice in our interactions and struggles. That's what made him stand out as a great Jewish leader, one who could be consistent with his stands on social justice, whether addressing Los Angeles or the Middle East. He helped me find my spirituality as a religious leader. He helped me see him as a brother in faith. 